\title{
The Coronavirus Pandemic: The Growing Relevance of Moral Cosmopolitan Justice?
}

\author{
Sumiti Kataria ${ }^{1}$ (D) Hongmei Qu ${ }^{1}$
}

Received: 11 January 2021 / Accepted: 29 September 2021 / Published online: 23 October 2021

(c) Fudan University 2021

\begin{abstract}
The essay attempts to conceptualise the adverse repercussions of coronavirus in an unequal global order. The changing security regime has intensified the increased probabilities of potential non-conventional threats. The coronavirus has uncovered the unpleasant realities of the socio-economic and political structure of the global north encountering financial crises and lack of health care resources. Contradictorily, the Pandemic has pushed the developing countries into the realm of extreme poverty, destroyed their minimum living conditions with the marginal provision of financial assistance. The contemporary unequal scenario exposed the unequal treatment for different social and economic classes questioning the neo-liberal policy discourse. Therefore, the central theme of the essay is to understand the multidimensional underpinnings of the health crises and global inequality upholding the relevance of cosmopolitan justice, adopting an analytical and deductive methodology of driving conclusions from general premises.
\end{abstract}

Keywords Unequal global order · Financial stagnation · Fragile Health System · Poverty $\cdot$ Neo-liberal policy $\cdot$ Cosmopolitan justice

\section{Introduction}

The Pandemic is a humanitarian crisis, the rapid spread of the contagious disease across the borders in several countries. (Huremovic 2019, pp. 51-52). According to the report of the "London School of Hygiene and Tropical Medicine, Imperial College, London and the Institute of Disease Modelling", coronavirus is 10-20 times fatal than seasonal influenza (Bheenaveni 2020, p. 183). Hitherto, the administration continued to ignore the seriousness of an existent health catastrophe for a relatively long period. The demarcation of national borders, rigid vigilance and extreme

Sumiti Kataria

sumiti.kataria17795@gmail.com; Sumiti.kataria17@outlook.com

1 School of Philosophy and Sociology, Jilin University, 2699 Qianjin Street, Chaoyang District, Changchun, Jilin 135124, China 
securitisation on cross-border movement seems extraneous to minimise the spread of coronavirus (He and Chen 2021). The development of technology and modernity through the globalisation process has aggravated the chances of people living in different countries being adversely affected by the virus, fostering the fierce discourse on the question of changing global economic order from globalisation to extreme nationalism or localism (Wang and Sun 2021; Yang and Chen 2021).

. The global exchange of commodities and increased mobility transforms into a rapid exchange of viruses. Subsequently, the intertwined international economic order and unequal political system raised subjective questions on the praxis of capitalist neo-liberal policy discourse trying to protect the operation of institutions amplifying a particular political ideology and safeguarding the economic interests of the dominant social group reflecting towards a retraction from transnationalism (Wang 2021; Huang 2021).

We must not forget; it is not the first time that we are experiencing a medical emergency. In the view of Damir Huremovic, "pandemics have played a vital role in determining the structure of society in terms of its demographic configuration, in anticipation of outcomes of the wars and to facilitate the innovation in technologies and medical sciences and public health" (Huremovic 2019, p. 07).

The global approach to promote the efficacy of social distancing, self-quarantine, the maintenance of personal hygiene and the sudden imposition of unplanned lockdown has disrupted the socio-economic structure and cultural configuration. The individual freedom of people was robbed to secure the long-term collective good of the societies or hide the unpreparedness of the health system. The world leaders have followed the utilitarian trajectory of the greatest happiness of the greatest number, without realising the unequal global structures as it is quite evident that the poor people will be the ones who would be the worst affected. The prevalence of fear and insecurity juxtaposing the Hobbesian state of nature, as the life of the people are at risk, and they are deprived of their liberties and rights, and if soon the situation would not be controlled, it might turn into a war of everyone against each other. One person will begin to view another as a danger loaded with an infectious virus (Beck 2000).

In a nutshell, the global Pandemic has instituted the domain of global risk society, notifying a paradigmatic shift from the recognised epistemology of security and stability to a realm of risk, instability and uncertainty jeopardising the conventional setup of order and control. The amplification of populist and pessimistic rhetoric of nationalism tends to generalise the growing intervention of state machinery, justifying authoritarianism as the only viable alternative to control the spread of Covid-19 (Huang 2021). According to Ulrich Beck, "A characterisation of the global risk society is a metamorphosis of danger which is difficult to delineate or monitor: markets collapse, and there is a shortage in the midst of surplus. Medical treatments fail. Constructs of economic rationality wobble. Governments are forced to resign. The taken-for-granted rules of everyday life are turned upside-down. Almost everyone is defenceless against the threat of nature as recreated by nature (Beck 2000, p. 219)". However, the critical analyses of social theory raised the intriguing argument of the construction of the politics of perception and normalisation of emergencies, using technological assistance such as media reports to either justify the act of government 
intervention in the private spheres or to ceal the failure of the state (Calhoun 2004, p. 387). One must acknowledge that calling out on the imaginary of conflict does not deny the probability of actual risk. But to raise an ethical obligation on the misleading portrayal of potential danger as an emergency to uphold the immediate and short-term plan to prevent the virus from forgoing the required long-term attention to understand the underlying cause of the problem and political will to initiate the praxis of social change and reconstruction in an unequal world (Calhoun 2004, p. 384).

Following the canon of risk society, the philosophical approach to cosmopolitanism becomes much more significant to direct our attention to existing international inequality and the dire need to redress the inequitable distribution of resources. There is no doubt that nationalism and isolation raise the egoistic binary of medical and vaccine nationalism without considering the actual risk of the global public health crisis that requires strengthening multilateralism and universalism (He and Chen 2021). The allocation of burdens and benefits is essential to contemplate mutual interests and social cooperation. According to Rawls, the basic structure of international relations identifies the nation-state as representatives of free and equal citizens. As the parties to the original position, the nation-states are entrusted with the responsibility to lay down the foundation of social cooperation and framework of primary maxims required to resolve the conflicting claims among reasonably just societies (Rawls 1999). The parties placed behind the veil of ignorance can only possess the necessary knowledge to make an informed choice. They do not have any relative information that might create biases, such as information related to the size, population, strength, possession of natural resources and their relative position in the field of economic development. For Rawls, the outcome of the process would be the selection of law of peoples, containing the principles related to self-determination, independence, non-aggression, self-defence, reciprocity, protection of human rights and the most important of all, the obligation of reasonably just and hierarchical societies to assist those who were jammed in unfavourable conditions of inequality, poverty and impoverishment and unable to sustain the primary goods that are necessary for the welfare of society as a whole (Rawls 1999). However, the Rawlsian premises of international law was not sympathetic to the proposition of distributive justice and institutional reform but restricted the force of cosmopolitanism to the negative duty of not causing harm and positive duty of mutual assistance, that has allowed the picturisation of global justice through the lens of bleak and pessimistic perspective immersed in the setting of anarchy and austerity.

Contradictory, Thomas Pogge rumination of cosmopolitanism derives from the insistence that the affluent nations are causing harm to the poor of the world (Pogge 2011, p. 21). He gave the example of how the institutional framework of the international monetary system, precisely the WTO intellectual property right policy, has significantly induced the gap between rich and developing countries and challenged the affordability level of developing countries to ensure access to the most prominent patent product (Pogge 2011, p. 26). In the wake of the Pandemic, the utilisation of medicine based on the highest bidding is ethically questionable. Pogge firmly believed that to trigger the collective obligation, it is significant to design the framework of institutional changes to reduce the disproportionate burden of inequality 
(Pogge 2011, p. 30). He suggested the strategic development of the Health Impact Fund that we will discuss later in detail to weigh down the overload of communicable diseases in developing countries, furthering access to pharmaceutical drugs (Holzer and Pogge 2021, p. 180).

According to Charles Beitz, the interpretation of international politics as a Hobbesian state of nature is philosophically flawed, premised on the assertion of states as the unitary agent who is relatively equal in power and independent in conducting their internal affairs with no prior expectation of reciprocal compliance. However, it must be acknowledged, the paradigm shift after the end of the cold war has altered the discourse of international relations in substantive and procedural ways. The growing influx of non-state actors - transnational financial institutions and international civil society organisations-have created new forms of power-structure that has aggravated the inequality between nation-states and coerced the least developed countries to seek dependence on the most developing countries for financial and technical assistance and broadened the scope of mutual compliance (Beitz, 1979). Beitz argued that "international relations is coming to resemble domestic society in several respects relevant to the justification principle of domestic social justice" (Beitz 1979, p. 128).

Pogge and Beitz have envisaged the intuitive idea to reformulate the course of action in order to reinterpret the Rawlsian theory of justice at the international level, where the contracting agents to the global original position will be aware of drastic inequality and the arbitrary possession of natural resources that positions few in advantageous conditions and others into the disadvantageous stage of underdevelopment. Consequently, advocated the resource redistribution scheme following the procedural mechanism of difference principle of resource endowment, providing the vulnerable with the assurance that they will be given a fair share of resources and just opportunities to establish social and political associations that will function in tandem with resource redistribution scheme (Beitz 1979). The institutional approach to cosmopolitanism, advocated by Pogge, precludes that the advent of global institutions, capable of enforcing the international laws and practices, will accelerate the ethical virtue of human rights discourse along with the realisation of our humanitarian duty to assist the most disadvantageous (Pogge 1992, p. 51).

Rawls expressed his disagreement with the postulation of global difference principle and argued that global difference principal work on the hypotheses of how the international structure is problematic and aggravating poverty in the global south, but failed to assess the existence of political asymmetry at the domestic level, affecting the development of egalitarian institutions necessary for the procurement of international guidelines for the protection human rights (Rawls 1999). Following the stipulation of Rawls, it can be interpreted that the collapse of the health system is not the responsibility of the global community but the negligence of domestic policymakers towards the health sector. Though Martha Nussbaum has also criticised the international difference principle for being too theoretical and speculative, she was critical of denying the human interest in the health sector and advocated the focus on building the global public sphere, envisaging the international community responsible for maintaining the ill health of elderly and disabled people (Nussbaum 2005). 
A critical scrutiny of cosmopolitanism cannot avoid the charges of moral hedonism and the inability of the global community to track the enforcement of moral duties. The impracticability of identifying the defector and the insufficient economic resources has created impediments towards realising the subsistence goals. The libertarian has allegedly supposed that the fulfilment of negative responsibilities is enough to maintain the procedural requirement of justice so long we have not consented to do otherwise, and if we failed to perform the negative duty, we owe the compensation to correct the injustice. Naverson argues, "Not all similarly agree that it is not, in general, our duty to make other people better off, and therefore not in general our fault when people are not better off than they happen to be, even if perhaps we could have made them so by efforts of our own. Nevertheless, I have seen no plausible argument that we owe something, as a matter of general duty to those whom we have done nothing wrong" (Gauri and Sonderholm 2012, p. 06).

David Miller has also raised the question of the contemplation of world government and assurance of reciprocity. He advances scepticism towards the theory of reinforcement of social justice at an international level. The implementation of the law requires a political community, sharing a common culture and common bond of solidarity that usually generate a sense of political obligation and people's allegiance to the constitution (Parjis 2007, p. 642). Nevertheless, Miller was consciously aware of the transformative structure of international politics and argued that "the concern of human rights overrides the concern for fairness and reciprocity" (Miller 2003, p. 128), and how the integration of the idea of providing assistance in the form of relief fund has modified the behaviour of nation-states from acting in the pursuit of domestic self-interest to the adherence of moral principle of doing in excess of what is required (Miller 2003, p. 126). The application of negative duty and the failure to recognise the moral requirement of the collective bargain and mutual interest scheme in the current scenario of Covid-19 can cause detrimental suffering to the health of underprivileged sections of the global community. The motive of assessing the philosophical debate around cosmopolitanism was not to accentuate the discussion on statism vs universalism but to promote a dialogue around our shared ethical responsibility. The Covid-19 Pandemic has given us the rationale to cultivate moral reasoning to make amends to the prevalent austerity and rectify the unjust structure of global politics ( $\mathrm{Gu}$ et al. 2021). The question is only how can we subsume the collective action problem. Therefore, the essay has conducted dual investigations of comparing the nature, scope, and approaches of the global north and global south in combating the threat of coronavirus and how we can operationalise the practicality of cosmopolitanism as an alternative policy discourse to configure a realm of equality, humility and inclusiveness.

\section{The Emergence of New Typography of Challenges: An Empirical Analyses}

The analyses of the conventional security system glorify the realist assertion of how the maximisation of state power and war is inevitable, and it is the only means to establish domination over the others. The accumulation of power has become an 
existential condition for the survival of nation-states. However, modern warfare has moved beyond using the conventional method of challenging the sovereignty of the states. Joseph Nye argues that the advanced securitisation process outweighed the traditional norm of protecting the national borders and emphasised the significance of social autonomy and political status (Haftendon 1991, p. 04).

Barry Buzan, in his book- "People, States and Fear"- underlines how the sole focus on building military capability is inadequate in protecting the lives of the people in a globalised world. He believed that it is not the states anymore who need the protection, but individuals are the new referent object. Buzan has identified several other realms of security such as political (with regards to the instability and corruption that prompts in the developing world), economic (focusing on the financial inequalities and the unequal distribution of wealth and resources), social (to protect the cultural identities in the multicultural societies) and environmental (to re-establish the balance between nature and human endeavours) (Williams 2013, p. 04). Nye and Buzan were unable to perceive health as a potential domain for securitisation as they lack the ability to foresee the probabilities of an epidemic changing the composition of our social security mechanism.

In 2004, the UN Secretary-General's High-level Panel on "Threats, Challenges and Change", put forward the report named, "A more secure World", recognised the six new branches of securitisation, namely economic and social threats reflecting the austerity of poverty, infectious diseases, inter-state conflicts, environmental degradation, terrorism and transnational organised crime (Williams 2013, p. 09). It was the first time that health was identified as a significant threat to human life. But the issue of health remains at the peripheries of policy agenda as the national government continued to allocate a large chunk of funds for fostering the offensive and defensive capabilities of nation-building, and no attention was paid to immune the health system.

After prolonged neglect for decades, it was realised that the health crises could pose a significant threat to the viability of humanity, and it is a considerable realm of securitisation. The development of public health care system requires enormous financial assistance to ensure the availability of medical apparatus, providing health insurance to its citizens to eschew the financial burden on poor households, proliferate the medical research for the innovation of new vaccines and medicines and even expand the ability to anticipate the future health catastrophe. According to the report of WHO entitled "Global Spending on Health: A world in transition" (2019), "health spending is transitionally globally, with a rapid increase in domestic spending both out-of-pocket and public-funded". 1 The health expenditure of high-income level countries observed abrupt growth. In 2001, The USA government spent $13.17 \%$ of its GDP on the development of the health sector. In 2017, the number increased to 17.06\%. The countries such as China (5.15\%), Germany (11.25\%) and Japan (10.76)

\footnotetext{
1 World Health Organization (2019). "Global Spending on Health: A world in transition”. Retrieved from https://www.who.int/health_financing/documents/health-expenditure-report-2019.pdf?ua=1, accessed on 6th May 2020.
} 
has allocated a fair share of their GDP for strengthening the public health care system in the year $2017 .^{2}$

The delayed attempt for reconstructing the health care system raised several critical questions exposing the exacerbation of disparity in the health system. The priority given to the military sectors subsume the ability of the state to predict the alternate source of the threats; consequently, the American health system is facing severe crises in the wake of the coronavirus pandemic. Inadequate health equipment in terms of lack of the ventilators, insufficient stock of medicine for treating the infected patients, forcing doctors and nurses to decide whom to kill, exposed the vulnerabilities and political failure of an ideology ingrained in consumerism.

According to Noam Chomsky, the shortage of ventilators uncovers the harsh realities of neo-liberal capitalism (Polychroniou and Chomsky 2020). No efforts have been taken to learn from the mistakes we have made during the past epidemics. Chomsky points out, despite the continuous statutory warnings, the Trump Administration deliberately chose to ignore the upcoming health catastrophe as investing in the health sector is unfavourable for the market operation. The government blocked the financial allocation of research agencies assiduously examining the relevant field. The social and moral responsibility of the corporate sector was overlooked for egoistic and profit-seeking ventures. The alliance between government institutions and corporate masters allowed the unlimited violation of the regulatory process, which would be regarded as a supreme offence of endangering human civilisation (Polychroniou and Chomsky 2020).

The President, Donald Trump, projected the Covid-19 as a "conspiracy of the left" to impeach his presidential rule. He stressed more on promoting myths about how the virus will disappear in the summer and reopening the economy than taking measures to prevent or contain the spread of coronavirus. Karin Pettersson argues how we are being misled by the account of given two alternate choices of either minimise the financial loss or to upgrade the health system. She says, "the economy is not only, or even primarily, a matter of profit or money but people's material conditions - the balance between work and capital, public health and unemployment" (Pettersson 2020).

The Trump administration failed to understand the more profound implication of the health catastrophe. He was not considerate towards the multidimensional nature of the problem and kept identifying the coronavirus aloof from its socio-economic consequences. The maintenance of good health facilities and the protection of social and economic security of the people are mutually interdependent. The sudden lockdown has deprived the people of their jobs, worst affecting the workers, daily wage earners and farmers. Trump administration was late to legislate the CARES ACT relief packages. Jerry Moran pointed out, "the U.S. coronavirus outbreak has caused more than $\$ 13$ billion economic damage to cattle producers alone" (Subramanian and Fritze 2020). A much more positive approach of state assistance will be required to minimise the damage. Joseph Stiglitz raised the question on the accessibility of

\footnotetext{
${ }^{2}$ World Bank Online Data (2020). "World Development Indicators". Retrieved from https://data.world bank.org/indicator/SH.XPD.CHEX.GD.ZS, accessed on 06th May 2020.
} 
the relief packages. He argued that "It has been a disastrous program, the money is not going to where it's needed most, the most vulnerable are not getting the money" (Hirsh and Johnson 2020). He also highlights how the relief package was formulated to push the commercial sectors not to throw the employees out of work (Hirsh and Johnson 2020). Therefore, the naïve response of the government has aggravated the sensation of mistrust, suspicion and scepticism judging the political intention of formulating policy discourse, leading to the deterioration of political institutions and democratic structure.

A much more consistent and coherent approach was comprehended to resolve the increasing threat of coronavirus in European countries as the European capitalist system was not premised on the thesis of neo-liberalism and laissez-faire of minimal state intervention (Makarychev and Romashko 2021). A strong partnership is observed between public and private entities. For instance, Germany successfully maintained a low mortality rate with rapid testing and tracking strategy. The German government managed to flatten the mortality rate curve with only 1.6 percent casualties of total infected cases, much less as assessed against the death rate in Italy with 12 percent, approximately 10 percent in Spain, France and Britain, 4 percent in China and around 3 percent in USA. ${ }^{3}$ The political commitment, trust and active participation of the citizens help the government to establish the mechanism to ensure better intensive care tools with the ample supply of ventilators and PPE (Personal Protective Equipment) kits.

In Denmark, the social-democrat government was quick to negotiate a crises package with trade unions, employers, organisations and other political parties to develop a much more rational policy of proclaiming nationwide lockdown on the one hand and providing safety nets to its people and business houses to ensure that they will not succumb to the disastrous effects of economic collapse (Berman 2020). Similarly, a much more trusted association was observed in Sweden between the state and its citizens. The administration urged the citizens to actively participate in assisting the government in fighting the battle against the unknown enemy and fulfilling their responsibilities, realising the sense of being part of a programme designed to ensure the greater good (Berman 2020). According to Prabhat Patnaik, crises have surfaced in the process of socialisation of health care facilities. The sudden nationalisation of private hospitals in Spain is an example of the inevitability of a capitalist structure to deal with the current health catastrophe (Patnaik 2020).

However, it is wrong to assume that the whole enchilada of neutralising the harm caused by the health catastrophe was adequate to minimise the nature and the scope of the problem. The European countries are also struggling hard to keep the death rate low, ensure sufficient health equipment and vanish the atmosphere of fear and uncertainty. The public administration failed to allocate the resources to the worst affected. It is also evident how the countries are caught up in the vicious circle of increasing fiscal deficit with the high number of unemployment and loss of

\footnotetext{
3 The New York Times (2020, April 4), “A German Exception? Why the country's Coronavirus death rate is low". Retrieved from https://www.nytimes.com/2020/04/04/world/europe/germany-coronavirusdeath-rate.html.
} 
small-scale industries. The so-called development model of focusing on economic growth and GDP, now crying out loud for the assistance of the state. We have been misled by the conventional method of perceiving economic growth as the sole criteria for judging the progress of the nation.

John Gerring highlights that "GDP per capita registers the mean (average) income among countries with diverse income distributions; consequently, the states of poor (or low-income households) may be quite different in countries with same per-capita GDP (Gerring 2007, p. 68)". Furthermore, he acknowledged the multiple variables of sustainability for the poor households, except the income. Therefore, the economic assessment based on the GDP and per-capita failed to emulate the welfare of downtrodden sections of the society (Gerring 2007).

For instance, UK is facing an acute shortage of ventilators and protective gear to ensure the safety of its medical staff. The British financial system marked the uproar of economic stagnation and the torpidity of fiscal deficit. The Guardian narrated the account of the British government compensatory policies for market rejuvenation. It was broadcasted that "the government Launched a job retention scheme to pay $80 \%$ of the wages of workers up to $£ 2,500$ each per month, the government has received applications for furlough payments from more than 387,000 firms to pay more than 2.8 million people, an intervention that has cost at least $£ 2$ bn so far, although a similar scheme to compensate the country's 5 million self-employed workers is planned, which will be established only by June, till then millions will receive no support under the current plans". 4

The political system of France also failed to develop systematic epidemic logistics tools to scale up the level of mass testing. The committee appointed by the government, consisting of 11 members related to the field of medical science, discarded the requirement of conducting extensive testing (Austermann et al. 2020, p. 214).

The collapse of the health care system and pondering the burden on the medical staff to decide whose life should be saved reflect the "state of imminent crises" as the political authority becomes the enemy of its own people's security. Following the narrative of social contract theory, people agreed to submit their absolute freedom to the political sovereign and adhere to the principle of political obligation for the protection of life, liberty and property (Lockean premises). The current threat on the lives of the people and state inability to perform is taking us back to the state of nature with no social stability, political freedom, economic capability and health security, questioning the framework of contemporary self-oriented, profit-seeking fragmented and unequal system of states.

Rawls argues that the stability of just constitutional democracy is premised on the political order of fair equality of opportunity, equal allocation of income and wealth, the establishment of the primary health care system, formulation of social and economic policies for the purpose of welfare and the availability of public information on the matters of policy discourse (Rawls 1999, p. 50). The historical analyses of

\footnotetext{
4 The Guardian. (2020) "What will Coronavirus mean for the British Economy?" Retrieved from https://www.theguardian.com/world/2020/apr/24/what-will-coronavirus-mean-for-the-british-economy, accessed on $09^{\text {th }}$ May 2020.
} 
movement towards democracy in the eighteenth century suggests the cost-benefit evaluation of policy formulation during the Pandemic will further create the waves of unstable social order to make people happier and satisfied. Raymond Aron calls such a state of peace "peace by satisfaction". He argues that the poisonous "pride of ruling", the expansionist plot of invading borders and the offensive strategy of building material or human resources will create pathetic conditions harming the establishment of lasting peace and social satisfaction (Rawls 1999, p. 47). The idea of "peace by satisfaction" will be lasting if it holds among all the societies establishing a constitutional regime to preserve human rights discourse upholding the moral and ethical values of entitlements ensuring basic subsistence for underprivileged sections of the community.

In conclusion, the shifting paradigm of international politics from territorial expansion to establishing social institutions working for the subversion of unalterable agony such as epidemics will bring more satisfaction to people (Rawls 1999, p. 48). The coronavirus has shown the concealed social and economic cleavages that might incite the populist movement challenging the governmental authority and the superfluous international solidarity against the egoistic traditional politics of realism favouring the discourse on human rights.

\section{An Increased level of Crises: Coronavirus tragedy in Global South}

The global south has been inflicted with the unequal and colossal burden of crises with the augmentation of coronavirus. Poverty, hunger and starvation, coupled with the health catastrophe, have led us to the nastiest phase in the history of human civilisation. It is not surprising as millions of people in developing countries are surviving on less than one US dollar a day (Cabrera 2016, p. 294). The findings of the United Nations Development Programme (2019) reveal the bitter truth of our unequal global structure encircled in the clutches of disproportionate allocation of resources with 1.3 billion people, i.e. $23.1 \%$ of the world population are forced to live in deplorable conditions with the non-fulfilment essential subsistence condition. In South Asia, $22.7 \%$ of children below the age of 5 encounters inequality in terms of deficiencies in nutrition within their households. ${ }^{5}$

According to the report prepared by UN Millennium Development Goals in 2015, people in developing countries are exposed to multiple vulnerabilities witnessing the increasing gap between urban and rural households. Approximately $16 \%$ of the village inhabitants lack a supply of clean and pure water resources. About $50 \%$ of people living in rural areas do not have the availability to sanitation and hygiene facilities, much less contrasting to the $18 \%$ of people living in metropolitan cities. ${ }^{6}$

\footnotetext{
${ }^{5}$ United Nation Development Programme (2019). Human Development Reports. Retrieved from http:// hdr.undp.org/en/2019-MPI, accessed on 09th May 2020.

${ }^{6}$ United Nations (2015). The Millennium Development Goals Report 2015. Retrieved from https://www. un.org/millenniumgoals/2015_MDG_Report/pdf/MDG\%202015\%20rev\%20(July\%201).pdf, accessed on 10th May 2020.
} 
The existence of such a low level of access to hygiene clearly illustrate how using soaps, sanitizers and masks, necessary to minimise the risk of coronavirus, is putting the financial burden on low-income households who eventually struggle to protect them or their family dying from starvation. The popular measures in terms of social distancing and maintaining personal hygiene to reduce the spread of coronavirus is undoubtedly a social privilege for those who can afford to be alienated and capable enough to purchase hygiene products. The underprivileged sections of the society residing in the clusters of close, congested and overcrowded settlements with no or significantly less access to sanitation facilities has naturally heightened the jeopardy of infection and death casualties. Farmer rightly elucidates that "inequality itself constitutes our modern plague, the burden of inequality primarily born by the poor and the marginalised, for not everyone can claim victimhood, despite the selfserving identity politics and 'soft-relativism' of our times" (Monshipourit 2001, p. 55).

As far as the public health system is concerned, the global health arrangements encounter an array of divergence, disparity and unequal patterns of financial allocation. According to the WHO report, entitled "Global Spending on Health: A world in transition" (2019), for poverty-stricken and developing countries, the average expenditure on health was only US\$41 a person in 2017, compared with US\$2937 in affluent countries-notifying the difference of more than 70 times. $^{7}$ The poor and marginalised are the last ones in the row of the beneficiary scheme. They have limited access to health insurance or entitlement to health care assistance, which has proportionately reduced out-of-pocket spending (OOPS) in affluent countries. Escobar, Griffin and Shaw showed a positive consensus on the relevance of health insurance to upgrade the public health care system not only as an outward financial protection scheme but as an affirmative procedure towards the reformation of health care beneficial scheme. They further contend that "the vast array of people involved in health care because they want to improve health- nutrition advocates, family planning advocates, tuberculosis and AIDS activists, vaccine supporters, Millennium Development Goal supporters, health system improvers- would have to see health insurance as an intervention that would be more effective in improving health outcomes than others directly focused options" (Escobar et al. 2010, p. 03). However, the national government or international community has made no radical efforts to scale up the coverage of the population through health care benefit policies or insurance and endowment schemes.

The upsurge of the Ebola virus epidemic in West Africa exposed the weak and delicate health care system with inadequate health officials and the shortage of medical staff. Even before the outbreak, Liberia's 4.3 million were served by just 51 physicians (Boozary et al. 2014), lacked financial resources to purchase the medical equipment and provide the safety nets to people.

\footnotetext{
7 World Health organisation (2019). Global Spending on Health: A world in transition, Retrieved from https://www.who.int/health_financing/documents/health-expenditure-report-2019.pdf?ua=1, accessed on 05th May 2020.
} 
According to Marie-Paule Kieny, WHO Assistant Director-General for Health Systems and Innovations, Outbreaks of contagious diseases can flare up anywhere; the spread of the Ebola virus in West Africa was triggered due to the deteriorated conditions of the public health care sector ${ }^{8}$ and the failure of national governments to mobilise the health equipment for the prior identification of symptoms.

The dreadful physical condition of the health care system is the biggest impediment in reducing the mortality rate in developing countries. The capability of the available network is far beyond handling the health catastrophe. Hence, it would be not wrong to say African countries will be worst affected by the Pandemic trapped in the vicious circle of multiple vulnerabilities in poverty, hunger, starvation, unemployment and encountering the crises in the health sector with the highest number of fatality rate. WHO has anticipated, during the first wave of the Pandemic, around 190,000 people could die in Africa due to the inefficient containment measures. ${ }^{9}$

The leading South Asian nation India is no exception. Globalisation has negatively impacted the public health care system in India. The legal binding of the structural adjustment programme (1991) emphasised the conditionality clause of downsizing the role of state apparatus and the unprecedented growth of the private health institutional structure, followed by massive disinvestment and cutting back on health subsidies. The marginal budgetary allocation (the expenditure on health was reduced from $1.3 \%$ in 1990 to $0.9 \%$ of GDP in 1999) adversely affected the capability of formulating an innovative epidemiological control measure (Roy 2016, pp. 226-227). Consequently, the multidimensional attack of coronavirus has exposed the fragile health care system, facing the overburden of infected patients with limited resources in terms of the unavailability of required ventilators, pharmaceutical drugs and PPE kits for the medical staff. It has been reported that PPE suits are only given to the high ranks physicians who are dealing with confirmed Covid-19 patients. The medical staff involved in the screening are facing the impeccable risk of infection. A considerable number of medical personnel are found positive with Covid-19 in metropolises like Delhi and Mumbai. The operation of health institutions with infected health officials was closed (Pandey 2020), stimulating the conundrum of decreasing number of medical staff and an increasing number of Covid-19 cases.

The slackness and negligence of governmental efforts to build a robust health care system have escalated the risk of infection and preponderances towards levying nationwide lockdown, without strategising and anticipating the detrimental effects it might pose on the subsistence of the deprived and marginalised sections of the society. The labour class lost their jobs and was thrown into the gutter of poverty, hunger and starvation. The affordability level of the labour class and fell to such an extent that they even find it difficult to feed themselves. They have not received any

\footnotetext{
8 World Health Organisation (2015). "Ebola recovery is impossible unless resilient health systems are rebuilt in Guinea, Liberia and Sierra Leone". Retrieved from https://www.afro.who.int/news/ebola-recov ery-impossible-unless-resilient-health-systems-are-rebuilt-guinea-liberia-and, accessed on 6th May 2020.

9 BBC News (2020, May 8). "Coronavirus: WHO Warns 190,000 Could Die in Africa in 1 Year". Retrieved from https://www.bbc.com/news/world-africa-52587408.
} 
financial assistance to put shelter on their head. The workers were compelled to walk miles to reach their homes as all the means of transportation were shut. The survey conducted of more than 3000 construction sites revealed that the Pandemic left more than $90 \%$ of labourers without any employment; $50 \%$ of them were helpless to afford the food grains for the day (Bhattacharjee 2020, p. 02). The announcement of relief packages under Provident Fund Scheme (Central government declaration of disbursing $24 \%$ of monthly income for workers earning less than Rs. 15,000 for the next 3 months), and direct cash transfer to the registered workers under the provision of Building and Other Construction Workers Act, 1996 (BOCWA) fall short of achieving its desired targets, covering only a minor segment of registered workers, leaving the workers engaged in unorganised sector unprotected (Bhattacharjee 2020, pp. 03-05).

The government failed to assess the nature of crises and delayed the process of arranging means of transportation, and that too, with a complicated registration process. According to The Hindu, migrants complain about the mismanagement of schedule. Most of them had no prior knowledge about the time and arrival and departure train station of Shramik trains (trains arranged for the workers). ${ }^{10}$

However, the south Indian state Kerala is managing the crises quite responsibly with a planned strategical account of establishing co-existence between the dual approaches of strengthening the health care system with the procurement of medical facilities and with the allocation the potpourri of safety nets to the poor and labour class through the organisation of community kitchen and Shramik Awaas (Quarantine Centres for Labourers), to ensure primary subsistence conditions. It is worth emphasising that the continued investment in the health and education sectors alleviated the capacity of the state to cope up with the Pandemic, with the closely-knit chains of health care centres facilitating the access of medical aid in the rural and under-developed regions (Sam 2020). The Kerala model proved that the incremental precautionary measures create an active realm of combating any future crises as a contrast to the immediate resolve strategy as it only neutralises the extent but fails to completely vanishes the catastrophic conditions.

\section{The Cosmopolitan Approach: An Alternative?}

The unequal global structure poses questions on the notion of shared responsibility. Coronavirus emerged as a health and financial crisis in terms of fiscal deficit for the affluent countries. The developing countries, on the other hand, struggling to maintain social stability. The virus has intensified the social and economic insecurities of the poor and marginalised sections of society. They are more afraid of dying out of hunger than the virus. Therefore, it is increasingly important to cooperate in strengthening the "southern consensus" against the so-called Washington consensus,

\footnotetext{
10 The Hindu (2020). Migrant Worker Continue to register to go home. Retrieved from https://www. thehindu.com/news/cities/Hyderabad/migrant-workers-continue-to-register-to-go-home/article31523139. ece, accessed on 13th May 2020.
} 
emphasising on deregulation, privatisation and capitalist economic structure. Article 25(1) of the United Nations UDHR (Universal Human Rights Declaration) clearly states that;

Everyone has the right to a standard of living adequate for the health and wellbeing of himself and of his family, including food, clothing, housing and medical care and necessary social services, and the right to security in the event of unemployment, sickness, disability, widowhood, old age or other lack of livelihood in circumstances beyond his control. ${ }^{11}$

The existential conditions of the Pandemic exposed the non-fulfilment of the universal goal of safeguarding and facilitating the human rights discourse. The structural inequalities imposed on the developing countries in the name of free trade and removal of tariff barriers for the smooth transaction of goods and services stands as a proactive agent of facilitating poverty with no social protection. The national governments are obligated by the international treaty to expedite cheap labour with minimum wages to the MNCs. It is not difficult to understand; the minimum wages are not sufficient for living an adequate life with basic amenities such as food, shelter, clean water and clothing. The minimum employment rate is only good enough to keep the person alive. It is regrettable, access to medicine and health care centre is a luxury for poor households, raising questions on the effectiveness of our shared responsibilities and collective action.

Thomas Pogge argues against the biased and unjust rule-making entity of international institutions. For instance; the TRIPS (Trade-Related Intellectual Property Rights) agreement provides a 20 -year patent right on the development of new medicine and grants the patent holders the monopoly of selling the drugs at the price as he deemed suitable, leaving the global poor excluded from the array of health care facilities and medicine (Pogge 2008, p. 75).

The TRIPS agreement fosters the realm of ambiguities after the innovation of the corona vaccine. Are we continue to reward the patent holder with his monopolistic value of cost? And if we do, how the developing and developing countries will be able to afford the price mechanism? What efforts domestic governments and the supranational institutional entity will take to further the equal accessibility of the corona vaccine? The growing spectrum of vaccine nationalism is quite observable. The deliberate attempts by the Trump administration to appropriate the rights of the vaccine being produced by the German pharmaceutical firm Cure Vac reflects the desperation of the national government to prioritise national interests against the moral canons of global responsibilities (Patnaik 2020). These emerging concerns have unravelled the tension between the binaries of just and equitable global structure and the hierarchical and stratified composition of international institutions and their binding covenants.

The epiphany of global ethics developed the consciousness towards the transnational moral problems and of our shared ethical responsibilities. Peter Singer argues;

11 Universal Declaration of Human Rights (1948). G.A. res. 217A (III), U.N. Doc A/810 at 71 (1948), Retrieved from http://hrlibrary.umn.edu/instree/b1udhr.htm, accessed on 14th May 2020. 
If it is in our power to prevent something bad from happening, without sacrificing anything of comparable moral importance, we ought, morally, to do it (Singer, 1972, p. 231).

The unequal positioning of people in a global order desperately yelling for intergovernmental cooperation to undo the previous hazards caused by the coronavirus pandemic. The smooth and cheap access to the corona vaccine will prevent something terrible from happening and act as an antidote to decrease the fatality rate across transnational borders. The global order requires the paradigm shift for the actualisation and realisation of abstract moral principles.

Rawls narrative of philosophy staged the critique against the utilitarian principle of maximising the marginal utility based on the calculation of resolving the moral problem based on consequence it produced. For Rawls, "the primary subject of justice is the basic structure of society, concerned with how social institutions distribute fundamental rights and duties and determine the division of advantages from social cooperation (Rawls 1971, p. 07)". The primary objective of distributional justice is to facilitate the discourse of a well-ordered society governed by the equal opportunity and difference principle, adhering to the moral reasoning of curtailing the pursuit of egoistic gains and move towards the altruistic realm of social justice.

He explains that the burdened societies are not inherently inferior, nor do they caught up in the competitive structure building material power, and neither did they mandate the exploitation against the minority community. What is unfortunate is the global order that deprives them of the required resources in terms of human capital and scientific technology and the sense of political culture solemnising the value of justice necessary for constructing a well-ordered society (Rawls 1999, p. 106). Therefore, the principle of the law of peoples (the application of political and legal conception of rights and justice on the international law) advocates that affluent liberal societies should owe the moral responsibility of benefiting the burdened societies following the philosophical rationale of distributive justice for the mitigation of global inequalities (Rawls 1999). The international institutions should pledge for the fair distribution of burdens and benefits with the reformation in the norms setting agendas.

The empirical supposition of the Pandemic legitimises the metaphysical doctrine of cosmopolitanism as normative philosophy of shunning the differences and identify an individual as the optimum element of our moral and ethical responsibilities, emphasising on the principles of individualism (the individual is sovereign that need protection), universalism (subject to universal moral values without any distinction based on nationality, community or group) and generality (people are unit of moral concern for everyone and everywhere) (Pogge, 1992, pp. 48-49). The cosmopolitanism attempts to equalise and correct the unjust global structure to protect the rights of the least well-off. It is the realisation of our moral duties towards the poor and disadvantaged. The unequal division of wealth and the appropriation of resources by the affluent countries have been excluded from the realm of justice. They are coerced to be victims of political authoritarianism, social injustice, economic insecurities and refusal of basic health care facilities. It is exceptionally significant now than ever to reject the false accusation of classifying cosmopolitanism as an 
ordinary abstract and ideal philosophical concept. The frequent exchange of material and human resources reached the point where the magnitude of conflict and the augmentation of social and political strive in one part of the world can be felt in the other part, which is quite observable during the coronavirus pandemic. Such apparent conditions validate the radical social change required for the reinforcement of everlasting global cooperation and protection of international human rights, and the unification of politics and morality.

According to David Held, globalisation has deepened the horizon of democratic participation across the borders and encouraged the adoption of an intrinsic approach to constitutionalise the rights that are significant to ensure the equal moral worth of the individual and justify the global domain for democratic participation to cherish the sovereign autonomy of the individual (Cabrera 2020, p. 69).

For Pogge, reforms in the global institutions are the pre-condition of empowering the global poor, and the strategised account of the "Health Impact Fund" will ensure the access of medicine even to the least well-off members of a global society. He argues, the HIF would prove adequate to eliminate the monopolistic price mechanism of pharmaceutical companies in exchange for the reward given for the innovation of new medicine (Pogge 2008, p. 76). The fair procedural requirements of drug registration will strengthen the expansion overseas at minimum cost to exchange rewards payments based on the assessment on global health impact based on the therapeutic value of cure. The patenting policy of HIF allows the autonomy to the firm to register the product wherever it pleases on the condition of selling it at a particular price across the globe throughout the reward period. The contract also specifies the clause of providing zero priced licenses of the required technology for the manufacture and distribution of the drug after the reward period (Pogge 2008).

The HIF strategy will recalibrate the affordability of the developing countries to reform the public health care system. The removal of the multifaceted interaction between government, pharmaceutical companies and civil society would diminish the marginal gaps between health inequalities. In the review process of HIF, it was argued that the designated low price might fail to empower the accessibility strategy, no matter how nominal the cost of the product is. People living in life-threatening poor conditions will not be capable of buying medicines anyway, particularly when they are struggling to gather food (McMullan et al. 2018). It poses challenges to the fundamental idea of HIF. The accessibility of HIF is also unknown to significant stakeholders. Though, the draft of HIF is going through the initial stage of verification. It would be wrong to judge the feasibility of any plan before its proper implementation (McMullan et al. 2018).

In some cases, the behavioural pattern of medical staff creates impediments on the way of shrinking the divide between poor households and the public health care system. The lower castes in India are denied treatment due to the prevalence of the age-old ruthless practice of untouchability. The historical evidence suggests Dalits were deprived of treatment during the influenza epidemic. Ambedkar highlights the contemplation of the nature of social prejudice in his writing "Untouchables or Children of India's Ghetto". He elucidates, "Very few people, even in India, know the extent to which caste determines the scope and objects of charities provided by the Hindus.... That caste can influence doctors in the ministration to the sick was a 
charge made among certain doctors in Bombay in 1918 during the influenza epidemic" (Sahu 2020). The existing conditions of Dalits failed to witness the radical transformation in actualising the ethical significance of social justice. The survey of "Untouchability in Rural India" investigated the roots of social exclusion in Indian societies. The outcomes of the research exhibit that Dalits were discarded from the entry in medical centres in $21.3 \%$ of villages. Research also discloses the caste prejudice of medical staff as they refused to deliver the treatment in $65 \%$ of Dalit occupied suburbs, leaving Dalits exposed to health vulnerabilities. ${ }^{12}$ The reduced price mechanism for medicine might alleviate the affordability level but failed to alter the existing social stratification in the health system.

Similarly, the Covid-19 impact on women observes an asymmetrical gender bias. The responsibility of maintaining the health of the family often falls on the shoulder of women, creating an additional burden on women to abandon their jobs and take charge of fulfilling the nourishment need of the family (Beck-Gernsheim 2000). Therefore, the probability of more women losing jobs in the labour market is rampant, which has caused severe anxiety and mental stress along with increased domestic labour among women, but the authorities have taken no attempts to formulate gender-sensitive relief packages.

The universal capability approach tries to provide a more coherent alternative evaluating the various valuable functioning as a part of life (Sen 2003). For Martha Nussbaum, in an international sphere, the capability approach necessitates the development of a list of entitlements that should protect the citizens sustaining the realm of just constitutional order. She argues that "we have a collective obligation to make sure people get what is due to them (Nussbaum 2005, p. 207)". The list of entitlements will include several functioning: to ensure adequate nutrition, access to equal educational opportunities, protection of bodily integrity, right to freedom of speech and religious self-expression (Nussbaum 2005, p. 208). However, Martha Nussbaum remains ignorant towards the practicality of accessing the global realm for the poor and marginalised. It is quite fractious to imagine that the person living below the poverty line will be aware of the entitlements enshrined in the list of capability development. The democratically elected governments of developing countries are struggling to get their voices heard in the international regime. They operationalise a very minimal stake in decision-making procedures. The unequal atmosphere of global institutions is the principal cause of the unequal division of burdens and benefits. For the construction of just global order, it is necessary that we ought to realise how the discourse on a social and economic structure is different in the global south from its counterparts.

To analyse the broader framework of the capability approach, Sen analyses the development as the elimination of significant sources of unfreedoms such as tyrannical and oppressive government, rotten and unequal economic opportunities, poverty-stricken and destitute conditions of living with the conjuncture of social

\footnotetext{
12 Humanitarian Aid Relief Trust (2016). India's Inequality in the Health Care: The Caste Divide. Retrieved from https://www.hart-uk.org/blog/indias-inequality-in-healthcare-the-caste-divide/, accessed on 6th May 2020.
} 
stratification and slackness of public facilities. He emphasised five types of freedom-political empowerment in terms of safeguarding the civil and political rights to ensure participation of every section of the societies, economic independence to ensure adequate income to alter the conditions of ill-literacy and ill health, social opportunities to shun the practices of social discrimination on the bases of caste, class, religion, gender and race, and to equalise the array of social opportunities, transparency guarantee to make our political system accountable to its citizens and protective security to provide safety nets in the form of subsidy and insurance and endowment scheme for the upliftment of the marginalised sections of society (Sen 1999, p. 19). The practical implementation of designated freedoms might expand the individual capability to encounter social and economic crises in their everyday life. But the primary question is, will it prepare the downtrodden sections to face the catastrophic effects of the Pandemic? To benefit the citizens, the political system should be transparent and empowered enough to work on the framework of moral righteousness. The corrupt and partial functionality of government lacks the motivation of upholding the welfare of its citizens ahead of themselves and creates an atmosphere of suspicion and mistrust, raising questions on the political relevance capability development approach.

The metaphysical modus operandi of cosmopolitanism demands an epistemological shift towards a hybrid account of moral responsibility, establishing reconciliation between national identity and global individualism. To reformulate the discourse on welfare and social progress, it is inevitable that we cogitate on the desire to move beyond the politics of populism, economic growth and profit-making approach of neo-liberalism emphasising on downsizing and disinvestment, purporting the reinterpretation of realist assertion international relations focusing on the conduct of inter-state conflict to the reflection on growing dependence and existing global inequality.

The adoption of HIF plan of action as an alternate model of arbitrary pricing mechanism of intellectual property rights can be a virtuous point of departure in furthering the accessibility and affordability level of the marginalised section to the health facilities, but at the same time, the focus should be on building a mechanism that also recognises the social and political impediments and emphasise on setting the global norms and operational guidelines to eliminate the structural barriers.

The multidimensional approach to cosmopolitanism attempts to construct a realm of fair distribution of duties and responsibilities that acknowledge the relevance of subsistence rights and the necessity of the global community to cooperate for creating an environment of social cohesion, providing the equal share of entitlements to the least-developed countries.

\section{Conclusion}

The essay tries to illuminate the strong interplay between the health catastrophe and its detrimental effects on the existing structural inequalities in the least-developed countries. Coronavirus revealed the hollowness of the pursuit of neo-liberal policy discourse. The conditions of human life were radically altered. The national 
government and international institutions failed miserably to ensure health faculties for the poor. The so-called civil society organisations, enchanting the slogan for strengthening the citizen entitlements to social and economic rights, kept staring at the plight of migrant labourers, and none took effective measures for the protection of the labouring class from hunger and starvation. We might overcome the coronavirus pandemic, but it is just a glimpse of the broader chains of crises waiting for us in the future. The global Pandemic has unravelled the dilemmas embedded in the premise of social theory. The correspondence of the development of diagnostic mechanism as a public policy formulation is much more complicated than outlining the diagnostic strategy in medical science based on scientific experimentation and following a cut-and-dried predetermined methodology. The societal problems are wicked and complex in nature. It requires not only the positivist problem-solving approach but also the capability to anticipate the casual chain of unseen future repercussions. Furthermore, consideration is needed to reconcile the pluralistic cultural values along with the reconstruction of unequal social and economic structure to restore the public faith in policy discourse (Rittel and Webber 1973).

Funding The author(s) received no financial support for the research, authorship and publication of this article.

\section{Declaration}

Conflict of interest The author(s) declare no potential conflict of interests with respect to the research, authorship and publication of the article.

\section{References}

Austermann, F., W. Shen, and A. Slim. 2020. Governmental Response to Covid-19 and its impact: A Brief Euro-Asian Comparison. Asia Europe Journal: Springer.

BBC News. 2020. "Coronavirus: WHO Warns 1,90,000 Could Die in Africa in One Year", Retrieved from https://www.bbc.com/news/world-africa-52587408, Accessed on 11th May 2020.

Beck, U. 2000. Risk Society Revisited: Theory, Politics and Research Programmes. In The Risk Society and Beyond: Critical Issues for Social Theory, ed. B. Adam, U. Beck, and J. Loom, 211-229. London: Sage Publication.

Beck-Gernsheim, E. 2000. Health and Responsibility: From Social Change to Technological Change and Vice Versa. In B. Adam, U. Beck, \& J. loon, The Risk Society and Beyond: Critical Issues of Social Theory (pp. 122-135). London: Sage Publication.

Beitz, C.R. 1979. Political Theory and International Relations. New Jersey: Princeton University Press.

Berman, S. 2020. Democracy, Authoritarianism and Crises. Social Europe. Retrieved from https://www. socialeurope.eu/democracy-authoritarianism-and-crises. Accessed on 07 May 2020

Bhattacharjee, S. 2020. Covid-19 and Labour Law: India. Italian Law Journal. 13(1).

Bheenaveni, S.R. 2020. India's indigenous idea of herd immunity: the solution for COVID-19? Traditional Medicine Research. 5(4).

Boozary, S. A, Farmer \& Ashish K. Jha (2014). The Ebola outbreak, Fragile Health Systems, and Quality as a Cure. Retrieved from https://jamanetwork.com/journals/jama/fullarticle/1915433?appId= scweb, Accessed on $11^{\text {th }}$ May 2020.

Cabrera, L. 2020. The Humble Cosmopolitan. Rights, Diversity and Trans-state Democracy: The Oxford University Press.

Cabrera, L. 2016. Poverty, Inequality and Global Distributive Justice. Ethics and International Relation, Ashgate Research Companion, p. 294. 
Calhoun, C. 2004. A world of emergencies: Fear, intervention, and the limits of Cosmopolitan Order. Canadian Review of Sociology 41 (4): 373-395.

Escobar, L., Griffin \& Shaw, . 2010. The Impact of Health Insurance in Low-and Middle-Income Countries, 3. Washington: The Brooking Institutions.

Gauri, V., \& Sonderholm, J. 2012. Global Poverty: Four Normative Position. The Journal of Global Ethics, $1-17$.

Gerring, J. 2007. Global Justice as an Empirical Question. PS: Political Science and Politics, The United States of America: Boston University, p. 68

Gu, Y., Qin, X., Wang, Z., Zhang, C., \& Guo, S. 2021. Global Justice Index Report 2020. Chinese Political Science Review, 322-486.

Haftendon, H. 1991. The Security Puzzle: Theory-Building and Discipline Building in International Security. International Studies Quarterly. 35 (1): 4.

He, Z., \& Chen, Z. 2021. The Social Group Distinctions of Nationalists and Globalists amid COVID-19 Pandemic. Fudan Journal of the Humanities and Social Sciences, 67-85.

Hirsh, M. \& Johnson K. 2020. The Tale of two Rescue Plan. Foreign Policy. Retrieved from https://forei gnpolicy.com/2020/04/24/united-states-europe-coronavirus-pandemic-shutdown-unemployment/. Accessed on 08th May 2020.

Holzer, F., \& Pogge, T. 2021. The Health Impact Fund: learning from Covid-19. In G. M. Padraig Carmody, \& G. M. Padraig Carmody (Ed.), COVID-19 in the Global South Impacts and Responses (pp. 173-180). Great Britain: Bristol University Press.

Huang, Q. 2021. The Pandemic and the Transformation of Liberal International order. Journal of Chinese Political Science, 1-26.

Humanitarian Aid Relief Trust. 2016. India's Inequality in the Health Care: The Caste Divide. Retrieved from https://www.hart-uk.org/blog/indias-inequality-in-healthcare-the-caste-divide/. Accessed on 16th May 2020.

Huremovic, D. 2019. Psychiatry of Pandemics: A mental health Response to Infectious Outbreak. Switzerland: Springer Nature.

Makarychev, A., \& Romashko, T. 2021. Precarious Sovereignty in a Post-liberal Europe: The COVID-19 Emergency in Estonia and Finland. Chinese Political Science Review, 63-85.

McMullan, P., Vamadevan, Srinivas, Bhalla, Prabhakaran, \& Banerjee. 2018. Improving Access to medicines via the Health Impact Fund in India: A Stakeholder Analysis. Global Health Action. Taylor \& Francis Group, Retrieved from https://www.ncbi.nlm.nih.gov/pmc/articles/PMC5844053/. Accessed on 16th May 2020.

Miller, D. 2003. Political Philosophy: A Very Short Introduction. United States of America: Oxford University Press.

Monshipourit, M. 2001. Promoting Universal human rights: Dilemma of Integrating Developing Countries. Yale Human Rights and Development. The USA, Vol. 4, p. 55

Nussbaum, M. 2005. Beyond the Social Contract: Capabilities and Global Justice. In G. Brock, \& H. Brighouse, The Political Philosophy of Cosmopolitanism. Cambridge: Cambridge University Press.

Pandey, V. 2020. Coronavirus: India's race against time to save doctors. BBC News, Delhi, Retrieved from https://www.bbc.com/news/world-asia-india-52215071. Accessed on 13th May 2020.

Parjis, P. V. 2007. International Distributive Justice. In R. E. Goodin, P. Pettit, \& T. Pogge, A companion to Contemporary Political Philosophy (p. 642). Malden: Blackwell Publication.

Patnaik, P. 2020. Pandemic and Socialism. Peoples Democracy. Retrieved from https://peoplesdem ocracy.in/2020/0329_pd/pandemic-and-socialism. Accessed on 03rd August 2020.

Pettersson, K. 2020. It's a Virus, and This isn't a war. Retrieved from https://www.socialeurope.eu/its-avirus-and-this-isnt-a-war. Accessed on 08th May 2020.

Pogge, T. 2008. Access to Medicine. Public Health Ethics. 1 (2): 72-75.

Pogge, T. 2011. Are We Violating the Human Rights of the World's Poor? Yale Human Rights and Development 14 (02): 21.

Pogge, T. 1992. Cosmopolitanism and Sovereignty. Ethics. The University of Chicago Press. 103(1).

Polychroniou C.J. \& Chomsky, N. (2020). Ventilator Shortage exposes the Cruelty of Neo-Liberal Capitalism. Retrieved from https://truthout.org/articles/chomsky-ventilator-shortage-exposes-the-cruel ty-of-neoliberal-capitalism/. Accessed on 17th May 2020.

Rawls, J. 1971. A theory of justice. Cambridge. Mass: Belknap Press of Harvard University Press.

Rawls, J. 1999. The Law of Peoples. Harvard University Press.

Rittel, H.W., and M.M. Webber. 1973. Dilemmas in General Theory of Planning. Policy Science 4: 155-169. 
Roy, A. 2016. Public Health Policy in India: A Critical Note. In Chakrabarty, B., Chand, P. Public Policy Concept, Theory and Practice. New Delhi: Sage Texts.

Sahu, S.N. 2020. Revisiting Ambedkar on Epidemics, Treatment Bias and Hindu Raj. Retrieved from https://www.newsclick.in/Revisiting-Ambedkar-on-Epidemics-Treatment-Bias-and-Hindu-Raj. Accessed on 12th June 2020.

Sam, T. H. 2020. Kerala Model against Covid-19: Not just communist, but a collective success. Retrieved from https://thecompass.in/kerala-model-against-covid-19-not-just-communist-but-a-collective success/?fbclid=IwAR0H4AtJt61pGYG3MEo2Cqa046CQ_OJKqFHO51Y_0cdW_i6p6muPTab zxTU. Accessed on 14th May 2020.

Sen, A. 1999. Development as Freedom, 19. New York: Anchor Books.

Sen, A. 2003. Capability and Well-being. Oxford University Press. Retrieved from http://existencia.org/ files/alt-eco/quality.pdf . Accessed on 11th May 2020.

Singer, P. 1972. Famine, Affluence and Morality. Philosophy and Public Affairs. Wiley Blackwell. 1 (3): 231.

Subramanian, C., \& Fritze (2020). Trump's \$19 Billion Relief Package for Farms Hurt by Coronavirus Includes Payments for Farmers. Retrieved from https://eu.usatoday.com/story/news/politics/2020/ 04/17/coronavirus-trump-announces-19-billion-farmer-relief-package/5157365002/. Accessed on 07 May 2020

The Guardian. 2020. What will Coronavirus mean for the British Economy? Retrieved from https:// www.theguardian.com/world/2020/apr/24/what-will-coronavirus-mean-for-the-british-economy. Accessed on 09th May 2020.

The Hindu. 2020. Migrant Worker Continue to register to go home. Retrieved from https://www.thehi ndu.com/news/cities/Hyderabad/migrant-workers-continue-to-register-to-go-home/article31523139. ece . Accessed on 13th May 2020.

The New York Times. 2020. "A German Exception? Why the country's Coronavirus death rate is low". Retrieved from https:/www.nytimes.com/2020/04/04/world/europe/germany-coronavirus-deathrate.html.

United Nations. 2015. The Millennium Development Goals Report, 2015. Retrieved from https://www. un.org/millenniumgoals/2015_MDG_Report/pdf/MDG\%202015\%20rev\%20(July\%201).pdf. Accessed on 10th May 2020.

United Nations Development Programme. 2019. Human Development Reports. Retrieved from http://hdr. undp.org/en/2019-MPI. Accessed on 10th May 2020.

Wang, Z., \& Sun, Z. 2021. From Globalisation to Regionalisation: The United States, China and PostCovid-19 World Economic Order. Journal of Chinese Political Science, 69-87.

Wang, Z. 2021. From Crises to Nationalism? The conditioned Effects of the Covid-19 Crisis on Neonationalism in Europe. Chinese Political Science Review, 20-39.

Universal Declaration of Human Rights. 1948. G.A. Res. 217A (III), U.N. Doc A/810 at 71, Retrieved from http://hrlibrary.umn.edu/instree/b1udhr.htm. Accessed on 14th May 2020.

Williams, Paul D. 2013. Security Studies: An Introduction. London: Routledge.

World Bank Online Data. 2020. World Development Indicators, Retrieved from https://data.worldbank. org/indicator/SH.XPD.CHEX.GD.ZS. Accessed on 06th May 2020.

World Health Organisation. 2015. Ebola recovery is impossible unless resilient health systems are rebuilt in Guinea, Liberia and Sierra Leone. Retrieved from https://www.afro.who.int/news/ebola-recoveryimpossible-unless-resilient-health-systems-are-rebuilt-guinea-liberia-and. Accessed on 11th May 2020.

World Health Organization. 2019. Global Spending on Health: A world in transition. Retrieved from https://www.who.int/health_financing/documents/health-expenditure-report-2019.pdf?ua=1. Accessed on 05th May 2020.

Yang, Y., \& Chen, X. 2021. Globalism or Nationalism? The Paradox of Chinese Official Discourse in the Context of the Covid-19 Outbreak. Journal of Chinese Political Science, 89-113. 